\title{
Emerging Branding Strategies and Value Creation Through Product Service System in SMEs
}

\author{
Özge Şahina, Gabriele Gorettia*, Qian XiaoBo ${ }^{a}$ \\ a Jiangnan University, School of Design \\ *Corresponding author e-mail: 8202001218@jiangnan.edu.cn
}

\begin{abstract}
:
Value creation is a significant key factor in branding strategies. Currently SMEs have a significant place in the worldwide development for each national economy and they can provide interesting branding processes. Product Service System (PSS) is gathering tangible and intangible features related to this topic. While the tangible features include the company products, whereas services can be considered among intangible features. In this paper, authors discussed on the role of PSS in brand values creation in the area of furniture industry SMEs. In particular, the study focuses on the definition of PSS mainly related to branding and how digitalizalization effect company assets. The research analyses Lago Design brand as a case study among the emerging European SMEs investigating on the effects of digital services in value creation and on the rising success of the company even during the COVID-19 pandemic era.
\end{abstract}

Keywords: PSS; SMEs; Furniture Industry; Resilience

\section{Introduction}

Brand strategy stands as a strategic management asset to set a proper company differentiation among competitors in the market. While branding and creating value are important for SMEs to grow in global competition, meanwhile adequate design skills and use the up-to-date technologies stand as key factors to succed at the global scale (Baporikar \& Deshpande, 2017). In this study the authors define Product Service System (PSS) and its implications into brand strategy and value creation. The research focuses on how these processes enable competitive assets through PSS in furniture industry.

According to the results of OECD $2010^{1}$, SMEs are the dominant forces in many economies around the world and make a significant contribution to the country's economy where they exist (Odoom et al., 2017). In particular, after globalization SMEs have realized on the importance of the brand value and PSS. According to this perspective, the research presents the brand Lago as a case study about

\footnotetext{
1 https://www.oecd.org 
Italian furniture. Italian furniture SMEs system stands as clusters of companies that produce by merging their knowledge in craft and different advance technological fields (Gabriele et al., 2019). Italian SMEs have significant place in global furniture industry and several successful Italian brands combine digitalization with traditional production methods within the supply chain (Fry et al., 2016).

\section{SMEs Economic Contributions and Their Position in the Worldwide Furniture Industry}

\subsection{SMEs Economic Contributions}

Global Value Chains (GVCS) are defined by OECD Skills Outlook, (2017): "Many products are now designed in one country and assembled in another country from parts often manufactured in several countries". Value chain has been defined by United Nations Conference on Trade and Development ${ }^{2}$ as all stages of all defined activities, including service and goods, from concept to distribution (United Nations Conference on Trade and Development, 2010). Companies produce their services and products by collaboration between companies in same country or among different countries according to GVC logic. Reviewing the history of many global brands - such as Apple, Adidas, Renault- it could be noticed that they started as SMEs and, because of growth, they established production sites and services in multiple countries across the world (Urata, 2021).

SMEs are generally positioned as subcontractors of global brands, as example in fashion industry. Usually SMEs produce raw materials or semi-finished products according to their capacities and they participate in global production (Goretti et al., 2019). On the contrary, in furniture sector SMEs generally own their independent brands, such as Italian brand as Poltrona Frau ${ }^{3}$ or Cappellini ${ }^{4}$. In particular, some SMEs in furniture design lead to supply chain or companies' cluster and also could deliver their final brand product.

Reasons of the importance of SMEs in the global economy could be listed as follows:

- They have close relations with the customer and respond quickly to the users' request;

- They can adapt to technological changes faster, in particular through technology transfers and cross-fertilizations among SMEs clusters (Fry et al., 2016);

- They can create more production and product variety, then they are flexible in manufacturing production according to demand;

- Creation of employment opportunities is higher than large-scale enterprises;

- They can make a consistent contribution to the country GDP by increasing their export;

According to the Second OECD Ministerial Conference of SMEs organized in Istanbul on June 3-5 2004, SMEs represented over 95\% of business in all countries (Buyuklukteki et al., 2019). SMEs represent between $30-70 \%$ in GNP, $40-80 \%$ in employment, 30-60\% in investments and $10-40 \%$ in exports (Enst et al., 2013). These data reveal to us the importance of SMEs in the country's economy.

\footnotetext{
2 https://unctad.org/

3 www.poltranofrau.com/en

${ }^{4}$ www.cappellini.com/en
} 
Table 1. Share of SMEs in Some Countries' Economies

\begin{tabular}{llllllll}
\hline & U.S.A & Germany & Japanese & French & UK & S.Korea & India \\
\hline $\begin{array}{l}\text { The place of } \\
\text { SMEs in all } \\
\text { businesses }\end{array}$ & 97,2 & 99,8 & 99,4 & 99,9 & 96,0 & 97,8 & 98,6 \\
\hline $\begin{array}{l}\text { Place in total } \\
\text { employment }\end{array}$ & 50,4 & 64,0 & 81,4 & 49,4 & 36,0 & 61,9 & 63,2 \\
\hline $\begin{array}{l}\text { Place in the } \\
\text { total }\end{array}$ & 38,0 & 44,0 & 40,0 & 45,0 & 29,5 & 35,7 & 27,8 \\
investment & & & & & & & \\
\hline $\begin{array}{l}\text { Place in the } \\
\text { added value } \\
\text { created }\end{array}$ & 36,2 & 49,0 & 52,0 & 54,0 & 25,1 & 34,5 & 50,0 \\
\hline $\begin{array}{l}\text { Place in total } \\
\text { exports }\end{array}$ & 32,0 & 31,1 & 38,0 & 23,0 & 22,2 & 20,2 & 40,0 \\
\hline $\begin{array}{l}\text { Share of total } \\
\text { loan }\end{array}$ & 42,7 & 35,0 & 50,0 & 48,0 & 27,2 & 46,8 & 15,3 \\
\hline
\end{tabular}

(Enst et al., 2013)

SMEs have significant place in all businesses and provide high percentage employment at some big economies country ${ }^{5}$ at Table 1.

\subsection{SMEs Place in Furniture Industry}

European Commission states on furniture industry as follows:

The furniture industry is a labor-intensive and dynamic sector dominated by SMEs and micro-firms. EU furniture manufacturers have a good reputation worldwide thanks to their creative capacity for new designs and responsiveness to new demands. The industry is able to combine new technologies and innovation with cultural heritage and style, and provides jobs for highly skilled workers.

The furniture industry companies present the following size indicators in the CSM $^{6}$ report (2017):

\footnotetext{
5 https://www.worldometers.info/gdp/gdp-by-country/

6 https://www.csm.toscana.it/en/home-page-en/
} 
INDICATE YOUR COMPANY'S SIZE

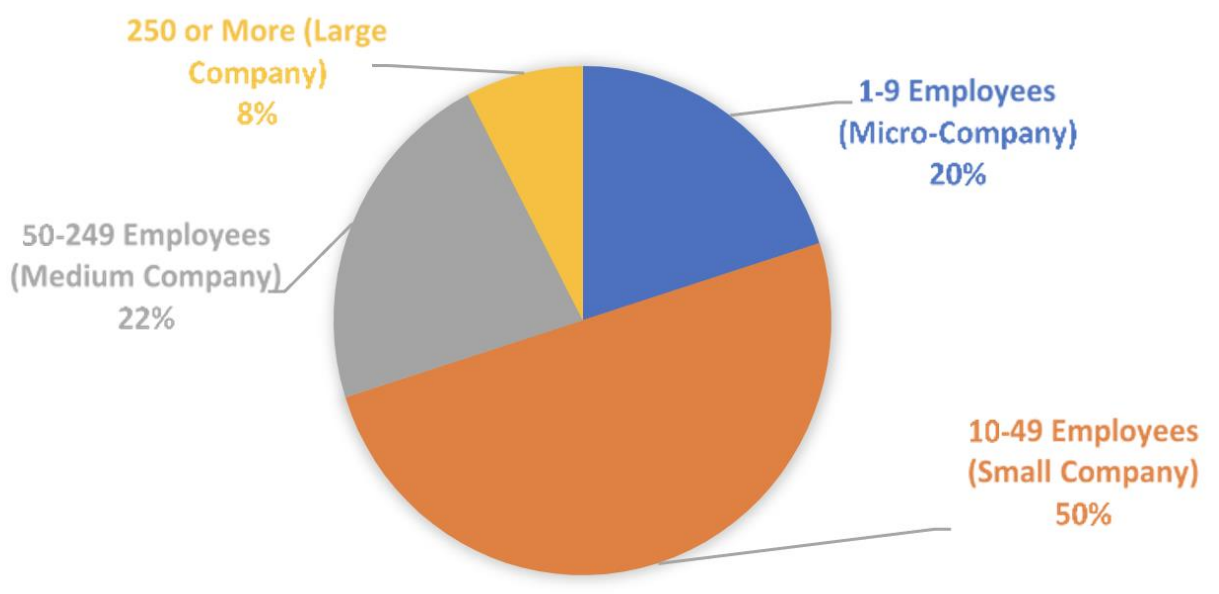

Figure 1. According to European Commission, SMEs hold a very important place in the furniture industry

(CSM, 2017)

According to Statista's $\mathrm{s}^{7} 2020$ report, the value of the worldwide furniture industry is 509.8 billion U.S dollars (Gelder, 2020). The role of SMEs is also positively affected by GVC. In fact, GVC could increase their skills at the global competition and could strengthen the SMEs in furniture production (Otero-Neira et al., 2009).

Italian furniture SMEs are taken as an example in such a high-value sector. Italy ranks among the top furniture exporting countries in the world (Kusumawardhani \& McCarthy, 2013). Most companies in the country comprise SMEs. They usually implement design-oriented innovations, instead of technology-based ones. Both strategies allow them to increase their competitiveness and help them open to the international market (Otero-Neira et al., 2009). Besides, investment in technologyoriented development may require a high budget for SMEs in the furniture industry (Masood \& Sonntag, 2020). By analyzing the market and ongoing innovation processes, it is possible to highlight integrations in between these two dimensions. In fact, after a design-oriented development, SMEs can strengthen their competitiveness and gain financial power, then they can set up a budget for technology-oriented investments.

\section{Value Creation Through Branding Strategies and PSS Design Significance in SMEs}

\subsection{PSS Definition and Its Importance in SMEs}

PSS could be implemented as a service method to sell products by considering customer needs (Mueller \& Thoring, 2012). Fulfilling customer needs through dematerialized services instead of using material-intensive products is defined as PSS (Hong et al., 2009). Solutions based on a mix of the material and immaterial components, which fulfill the requirements of each of the actors (companies, institutions, and final users) are described as PSS (Morelli, 2006). This operational model

\footnotetext{
${ }^{7}$ https://www.statista.com
} 
is stronger than traditional business ones and puts the customer at the center (Dewberry et al., 2013). By combining service and product, PSS increases the values and artifact performances for the customer (Marilungo et al., 2017). In fact, according to Tukker's definition, a concrete product and an intangible service are combined and designed to meet the customer's specific needs (Tukker, 2004).

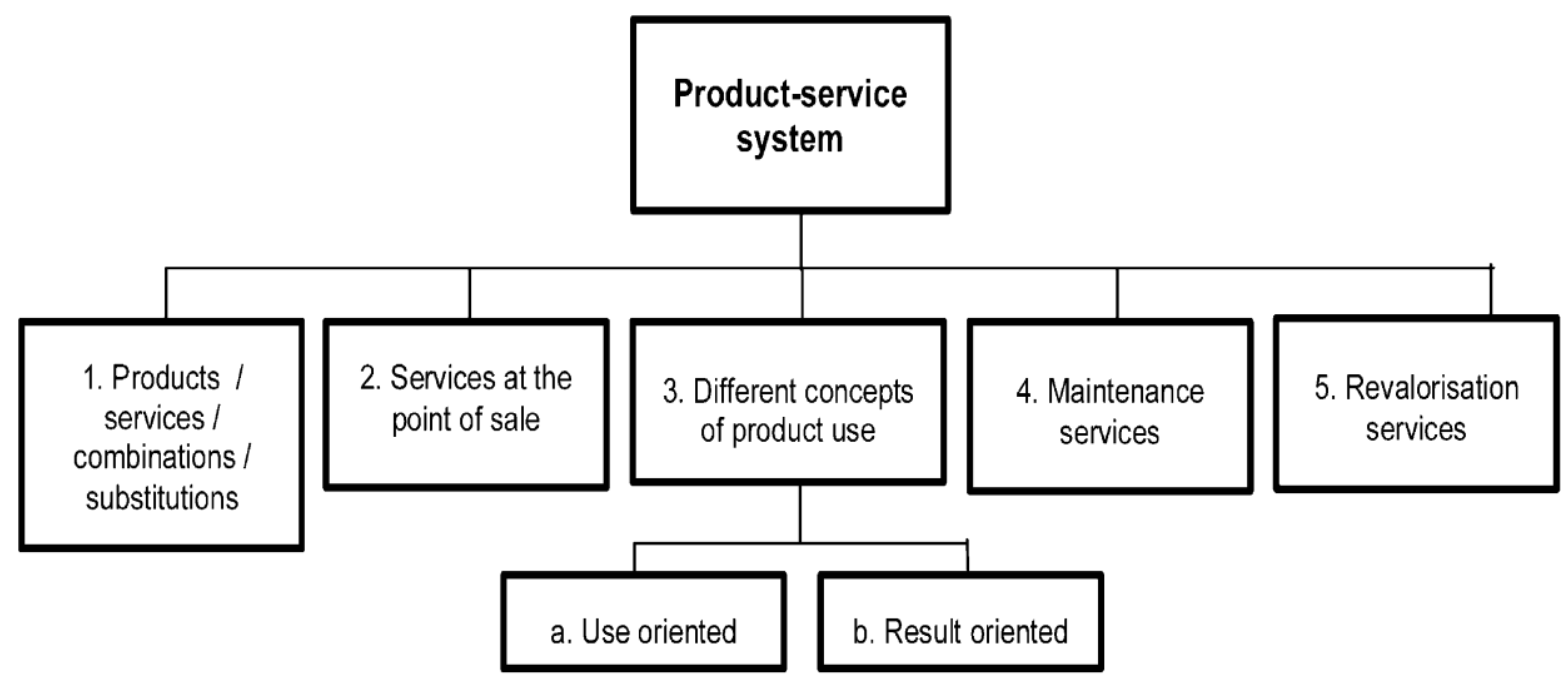

Figure 2. PSS chart

(Hong et al., 2009)

The figure provides th main PSS elements, according to the common terms of studying PSS.

PSS could be one of the most important systems that enable SMEs to increase their quality and follow innovations with service-oriented production and sales (Bhamra et al., 2018). PSS might reshape the design process, create customer value and new business opportunities, increase competitiveness, allowing the companies to reach new markets.

According to Bhamra (2018), through the adoption of PSS strategy it is possible to achieve the following results:

1. The quality of SMEs improves and service orientation is implemented within the production process;

2. They move from product-oriented solutions to service-oriented solutions;

3. Service focus generates significant reorganization in SMEs, and customers' consumption and brand perception change with them.

\subsection{Branding and Value Creation within SMEs' Strategy}

The American Marketing Association" proposed the following definition of a brand: "A name, term, sign, symbol, or design, or a combination of them, intended to identify the goods or services of one seller group of sellers and to differentiate them from those of competitors." Besides, a brand is everything that a product or service expresses to consumers (Kotler \& Armstrong, 2012).

Brand is helping customers in a particular standard, showing them given benefits and quality (Paksoy et al., n.d.). Moreover, it stands as a kind of guarantee. Through an effective own brand, a company

\footnotetext{
8 https://www.ama.org/the-definition-of-marketing-what-is-marketing/
} 
can differentiate from other market players that sell similar products, gaining a certain customer base.

SMEs can grow and increase their competitiveness through strategies despite limited capital and various constraints. Branding contributes to the continuity of a company and the extension of the enterprise's potential to future generations. Therefore, SMEs should also create their own "trademark" and investment opportunities should allocate for it (OZCAN, 2008).

Marketers often aim to keep the brand in mind, buy the product and service, and share the story of the customer who experienced it; among the most effective ways to do this, storytelling and customization have become two trending topics on the digital platform again in the last few years (Taft, 2019). For instance, Artemest furniture brand applies storytelling and customization strategy in many of their high-end products.

While Viabizzuno focuses on products designed with a smart power supply and an innovative heat spreader, the customer who has a problem with the product can send the product back to the company and receive the new product, while the company aims to further improve the product by renewing the old product with new and better technology; the company equates this with innovation in sustainability (Pagliacolo, 2015). In summary, Viabizzuno emerged the brand value from their technical value.

\subsection{SME's PSS Design Approach LAGO Design-Case Study}

Several furniture SMEs in Italy stand as significant case studies about effective implementations of up-to-date technologies in different production fields. Despite that, traditional craftsmanship knowhows are at the center of Italian design-oriented SMEs (Gabriele et al., 2019).

LAGO Design is a brand that started its interiors work in villas and churches at the end of the 19th century and showed itself in the international market with the fourth generation. They implemented a 3D Configurator, thus the customer has the chance to participate in the production design. Besides, service-oriented production approach takes customer requests into prime consideration. The company offers service-oriented solutions, by product-oriented solutions. In summary, PSS enriches the customer experience and creates brand value.

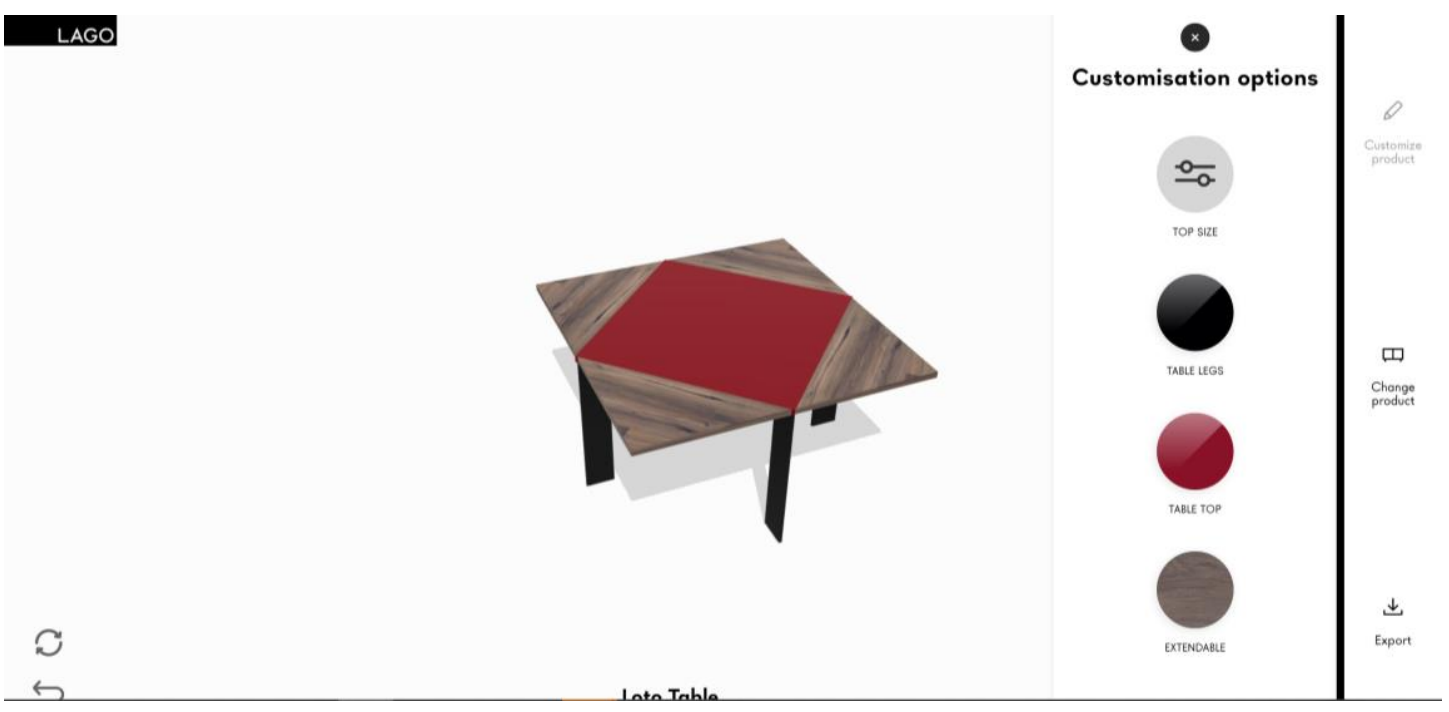

Figure 3.LAGO`s 3D Configurator for their customers

(LAGO, 2021) 
LAGO sees design as a tool that helps to understand and fulfill the needs of the modern world. By involving the customer in production, the company could be updated about contemporary market trends and might improve the traditional craftmanship know-hows through "out of the box" perspectives. The rapid change of production and service by adapting to customer needs and innovation embodied an effective brand strategy.

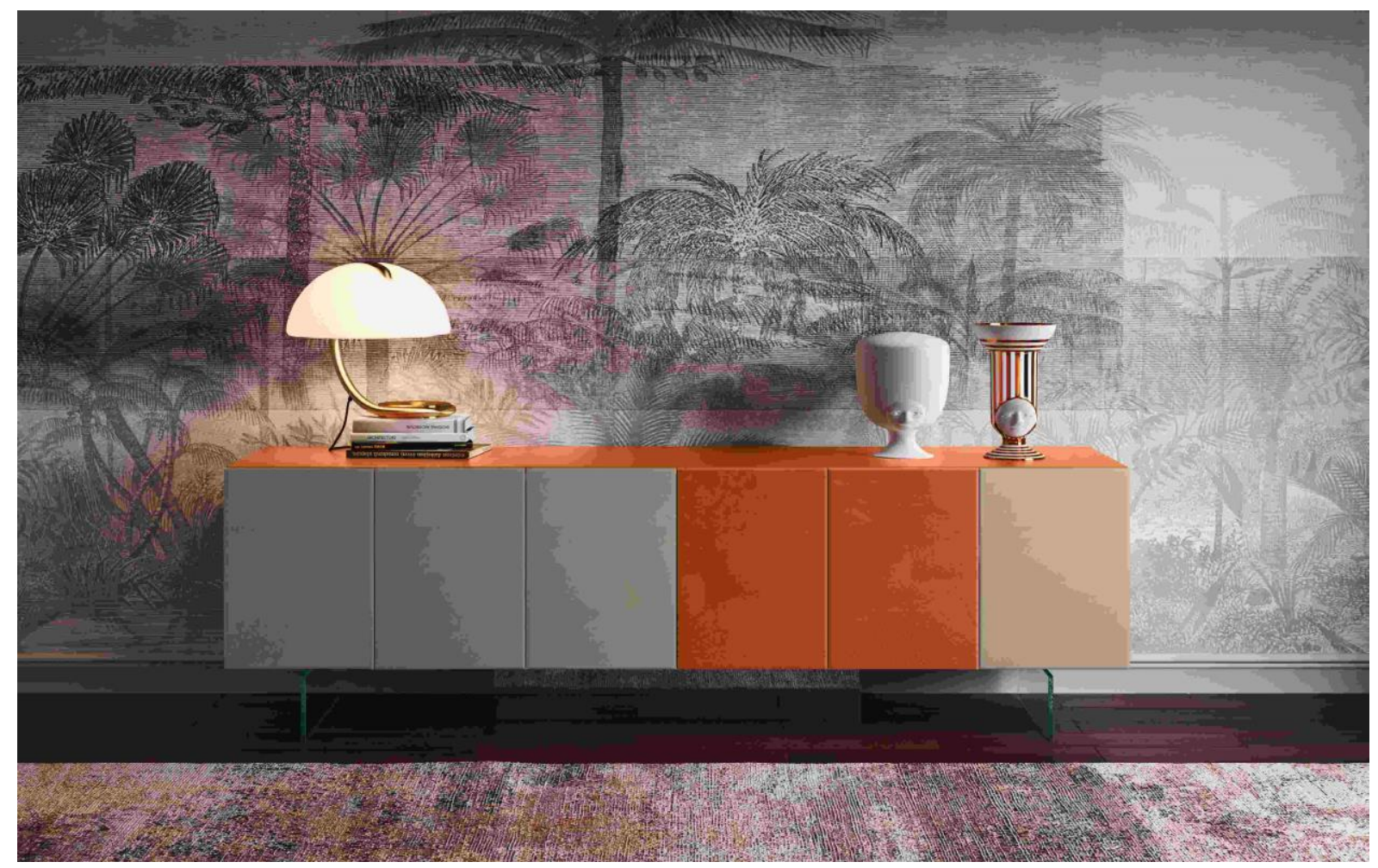

Figure 4. LAGO Design XGlass innovation on the traditional furniture

(LAGO, 2021). 


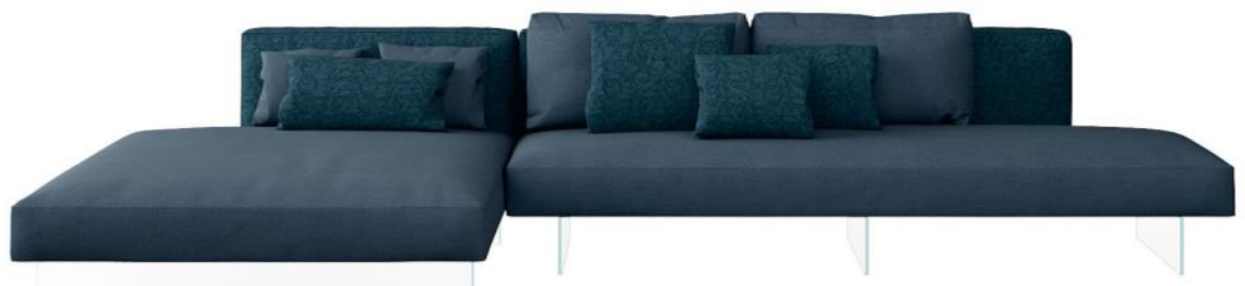

Figure 5. LAGO Design Divano Air Damascato

(LAGO, 2021).

\section{PSS with Industry 4.0 Programs}

\subsection{Industry 4.0 for SMEs}

SMEs, which apply Industry 4.0 from a technological and organizational perspective in order to make the existing craft-oriented traditional production methods more digital and rational, structure their flexible business model. Thus, companies experience "smart" transformations in terms of logistics, such as Smart Lifecycle, Smart Supply Chain, and Smart Factories.

Industry 4.0 is the combination of production, information technologies, and the internet (Rauch et al., 2020). In fact, internet service increases the competitiveness of the companies and thus profitable PSS emerges. According to OECD research, when service and production-oriented thinking develop together, that gives better profit to company (Mueller \& Thoring, 2012). Today, the technology-lacking company scarcely succeeds in the competition. Only fast, high quality and lowprice production does not provide an advantage in competing with other companies; new innovation and digital production strategies have gained rising importance (Rauch et al., 2020). 


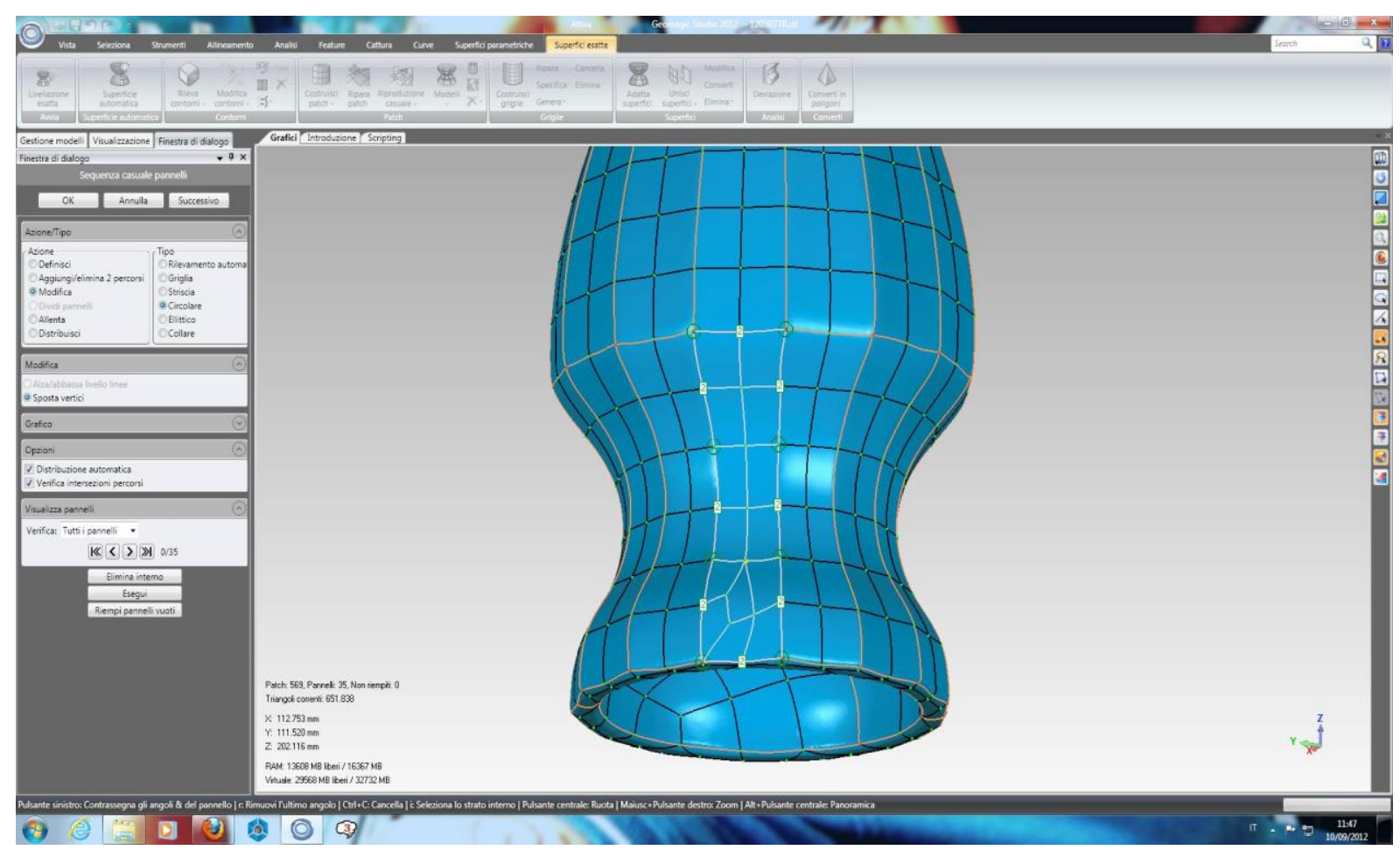

Figure 6. Parametric design in solidworks software

SMEs have limited budgets to invest in technology, so Industry 4.0 is not easily applicable for SMEs and then to compete with large companies. According to manufacturing 4.0, the entire company must work in an organized manner and SMEs managers need to learn this in-depth (CSM, 2017) even if it is difficult to implement it on a small scale.

Horizon 2020 is a significant program in which the European Union supports individual researchers, multinational cooperation projects, and SMEs by providing research and innovation funding (EU Neighbours, 2020). There are many projects in order to boost innovation and technological development in SMEs in the furniture sector, such as IN4WOOD, DITRAMA, EQ-WOOD. Generally speaking, the furniture industry is a field where technology is not used extensively in production, it's a low-tech industry (Otero-Neira et al., 2009). However, in order to increase brand value and strengthen competition, it is important to provide digital transformation within the company with technological developments.

\subsection{Pandemic Effects in PSS Design- Lago Case History}

During the pandemic, homes often became offices and people would like to separate the workplace from living space, changing their furniture. The research highlights how in this period people had a rising request for new furniture and new aesthetic for the home to furniture companies. The import rate of the world's upholstered consumption in the furniture sector has reached $34 \%$ during the pandemic (THE WORLD UPHOLSTERED, 2019).

SMEs are quickly affected by changes and environmental problems, and resilience has become important for their continuity throughout the pandemic process (Zuperkiene et al., 2021). On the other hand, SMEs could adapt quickly to changes and gain strength by learning from this difficult period. Introducing PSS could strengthen their work, organization, and management. LAGO's digital business culture, which is intertwined with the brand, dates back to decades. Despite the 500 physical stores of the brand, the company also had the opportunity during the pandemic to work on customer demands for furniture renovation. LAGO Design created an omnichannel system under the 
title of "shopping experience". This project meets the design and customers' needs through 3D visualizations, helps customers to visit LAGO stores in real-time, and helps them discover their latest collections and new products (Archiproducts Logo, 2020). LAGO quickly adapted consumers' needs and created its "Home Office" collection and renovating furniture during the pandemic. In addition, the company offers online meetings between customers and brands designers, customer-oriented and flexible product design and services, or phone applications.

Besides, according to the company communication, LAGO shows intensive strength in services, and they opened a new branch in Shanghai during the epidemic (LAGO, 2021b).

\subsection{Digitalization Effect on SMEs}

According to Digital SME Alliance ${ }^{9}$, the opportunity to progress in digitalization has emerged with the crisis that occurred with the pandemic events, and summarizes the process as follows (European Digital SME Alliance, 2020):

It's very important for SMEs to develop digital skills, participate in change programs to reduce the risk of unemployment, invest in digitalization, facilitate purchasing across borders, and receive support from various organizations and the government for digital transformation. SMEs and local people are not only users but also shapers in this technological change.

Business, meetings, shopping and marketing are mostly carried out in the virtual environment during the pandemic worldwide. During this time, companies generally enlarged their focus on technologyoriented digitalization in the service area. Service innovations affect products presentations and marketing strategies. Digital catalogs, phone applications help the customer to better understand product values requests and to access the company qualities. In addition, such digital updates in one field of the company can affect other fields of the company too, generating and integrated management innovation.

Savio Firmino in Florence, who faced global competition since 2015 through the digitalization by 3d scanning and digital archive, and the company has increased its flexibility in the market by innovating its production processes so that the company can more easily follow trends (Goretti \& Denaro, 2021). Images of Savio Firmino "Digital Archive" about "Notte Fatata" kids collection for Asian Market:

\footnotetext{
9 https://www.digitalsme.eu/
} 

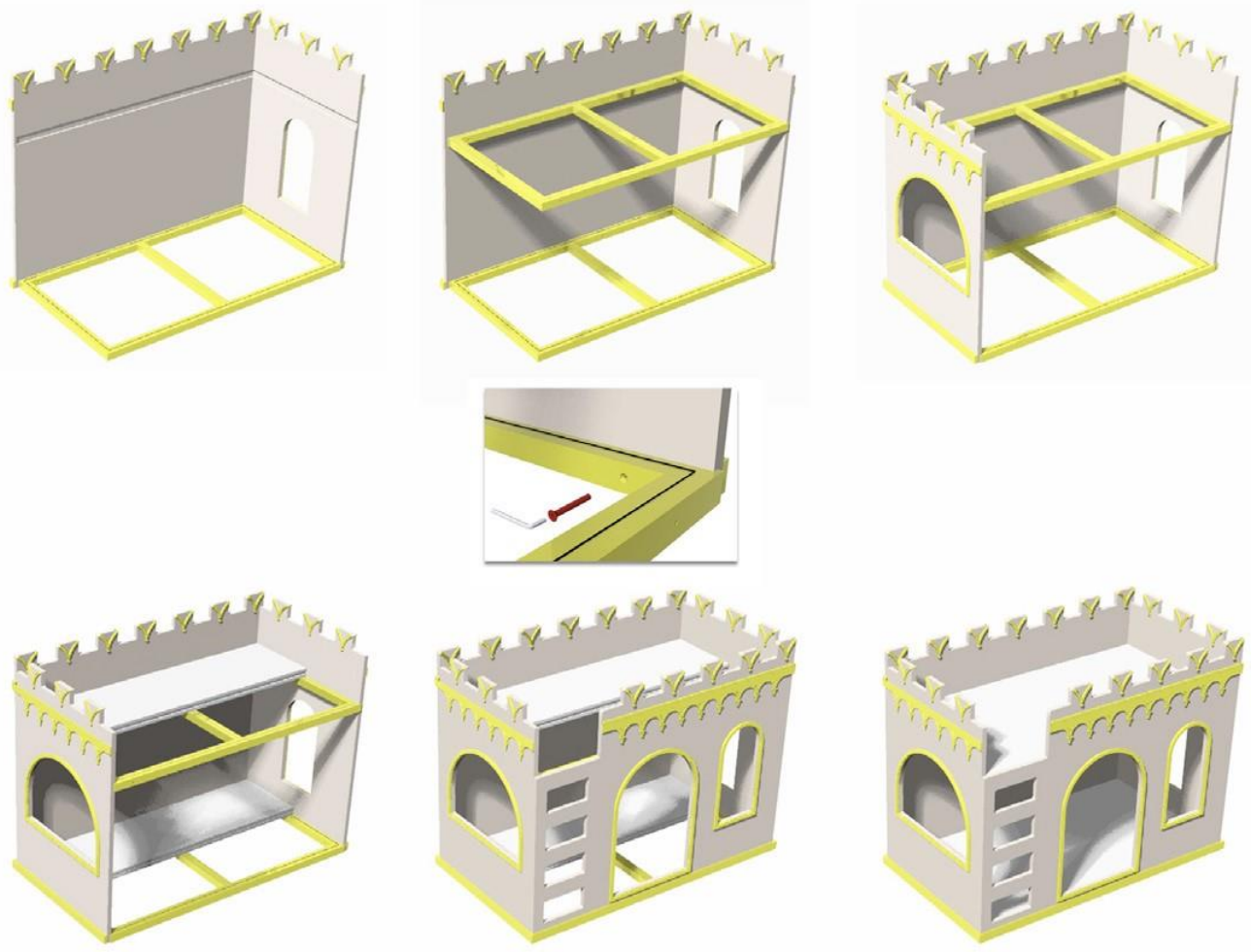

f

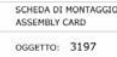

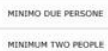

Figure 7. Savio Firmino Digital Archive

(Firmino, 2021)

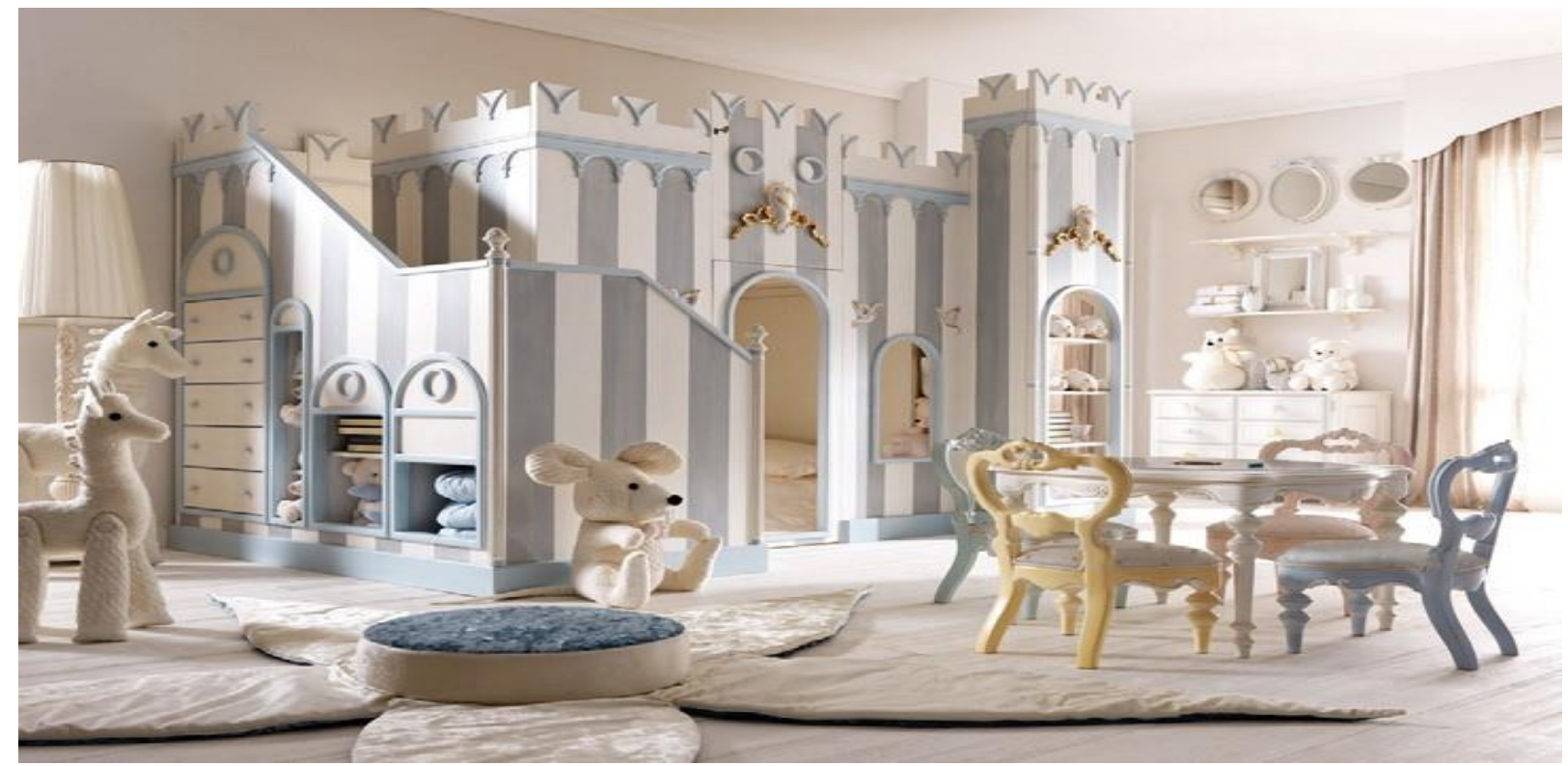

Figure 8. Savio Firmino "Notte Fatata"

(Firmino, 2021)

Luisaviaroma, a company specialized in furniture characterized by craft products, customer expectations, and design. Besides, the company has been focusing on online services since 1999, and 
$90 \%$ of total revenue is from online sales (Luisaviaroma, 2021). Their success in digitalization and their success in online international sales in clearly visible related to each other. Finally, it is possible to assume that digitalization in shopping can be considered as a new trend for many brands and many customers. Adapting to this experiential service part could affect the brand value, it is an important opportunity for digital reorganization and could represent a strategic path to develop resilience qualities.

\section{Conclusion}

The paper presents as SMEs in the furniture industry have usually made design-oriented innovations, and then they might create a budget to incorporate technological innovations too.

During the pandemic, responding to customer needs faster and more effectively through digital devices became more important. Besides, PSS could represent a new phase in SMEs supply chain, by structuring new channels to interact with the customers. The combination of technological transformation of manufacturing and PSS could significantly increase the competitive skills. Further digitalization, custom visualizations to offer a larger product range could be helpful to interact with customers. This integration could affect the brand value of the company. Then, Industry 4.0 in production could be connected to the service design to provide new experiences for the users. That process could allow to a resilience effect, based on emergency issues and skill on learning from difficult moments and setting a quick adaptation of changes.

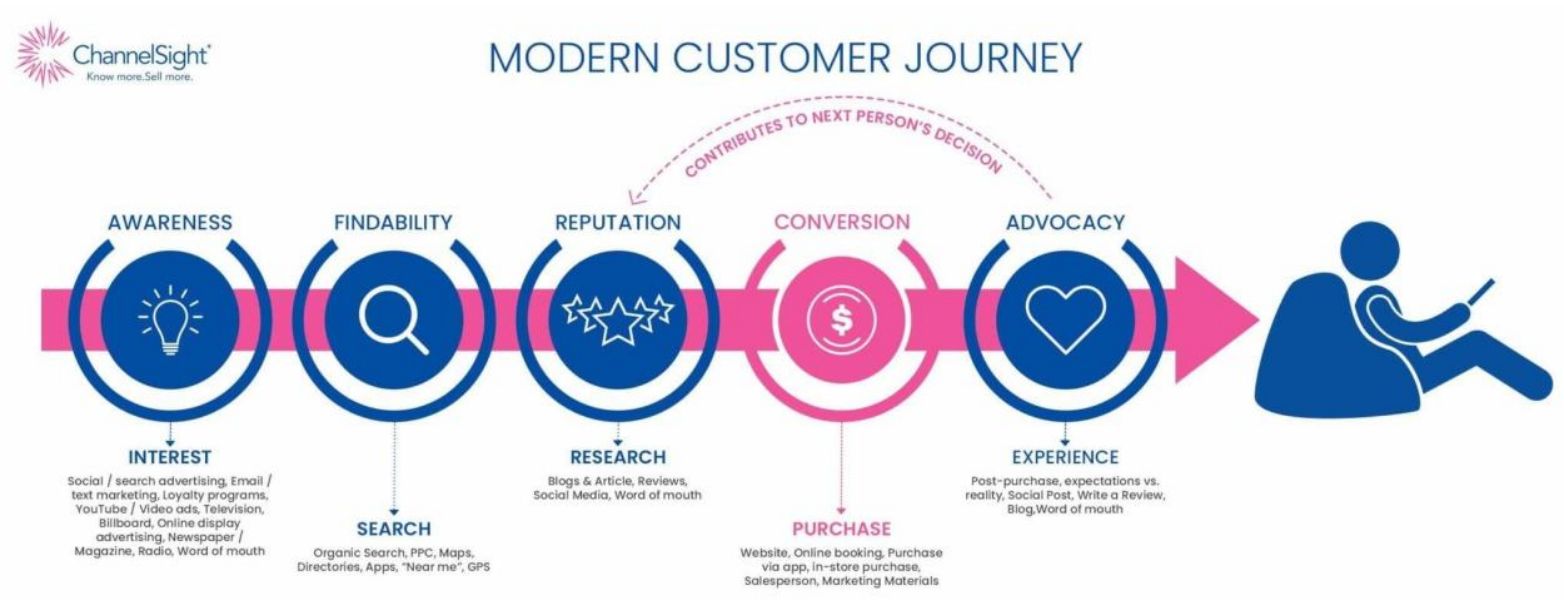

Figure 9. Customer Journey Map

(ChannelSight, 2021)

According to Caroll's description: "The scenario could be the design object and may be augmented and rearranged as the design evolves. It can become a hypothetical interaction scenario for a new design and allow better understanding of the new design" (Lameman et al., 2010). As primary research, a deeper "scenario-based design" could be considered to define the context of interest and purchase. 


\section{References}

Archiproducts Logo. (2020, November 13). Lago Shopping Experience. https://www.archiproducts.com/en/news/lago-shopping-experience_79600

Baporikar, N., \& Deshpande, M. (2017). SMEs and Branding Strategies. International Journal of Applied Management Sciences and Engineering, 4(1), 43-55.

https://doi.org/10.4018/ijamse.2017010104

Bhamra, T., Hernandez, R. J., Rapitsenyane, Y., \& Trimingham, R. (2018). Product Service Systems: A Sustainable Design Strategy for SMEs in the Textiles and Leather Sectors. She Ji, 4(3), 229-248. https://doi.org/10.1016/j.sheji.2018.07.001

Buyuklukteki, O., Uzerine, I., \& Arastirma, B. (2019). MuhasebBilgiSistemleri: Kucuk Ve.

ChannelSight. (2021). Modern Consumer Journey: Everything You Need to Know. https://www.channelsight.com/blog/modern-consumer-journey-right-message-at-the-right-time

CSM. (2017). Report of the need of the furniture industry regarding KET of 14.0. 1-85. https://in4wood.eu/wp-content/uploads/2017/12/D1.2.pdf

Dewberry, E., Cook, M., Angus, A., Gottberg, A., \& Longhurst, P. (2013). Critical reflections on designing product service systems. Design Journal, 16(4), 408-430. https://doi.org/10.2752/175630613X13746645186089

Enst, M., Ve, U. B., Programi, S., Tezi, L., \& Tanyer, S. (2013). Kobi ' Lerin Türkyie Ekonomisideki Yeri Kobi 'Lerin Türkyie Ekonomisindeki

EU Neighbours. (2020). https://www.euneighbours.eu/en/east/stay-informed/projects/horizon-2020

European Digital SME Alliance. (2020). COVID-19 Economic Recovery: A Recovery Strategy Building on Digital. May.

Firmino, S. (2021). Child Dreams. https://childreams.com/

Fry, A., Goretti, G., Ladhib, S., \& Cianfanelli Elisabetta; Overby, C. (2016). Advanced craft" integrated with the saper fare; the role of intangible value, and the centrality of the artisan in highquality 21st century artisa. Cuaderno journal, Cuaderno Journal, Emerging Processes in Design Practice and Design Education, University of Palermo Buenos Aires (Argentina)

Gelder, K. van. (2020). • Furniture market value worldwide 2027 / Statista. https://www.statista.com/statistics/977793/furniture-market-value-worldwide/

Goretti, G., Cianfanelli, E., Terenzi, B., \& Tufarelli, M. (2019). Advanced Craftsmanship nell'arredo. II comparto toscano tra tradizione e innovazione 4.0 / Advanced Craftsmanship in furniture. The Tuscan sector between Tradition and Innovation 4.0. DIID jiornal, Design Actually, 26-33.

Hong, T. P., Lin, W. T., Chen, C. H., \& Ouyang, C. Sen. (2009). Learning membership functions in takagi-sugeno fuzzy systems by genetic algorithms. Proceedings - 2009 1st Asian Conference on Intelligent Information and Database Systems, ACIIDS 2009, 10, 301-306.

https://doi.org/10.1109/ACIIDS.2009.18

Kotler, P., \& Armstrong, G. (2012). Branding BOOK.

Kusumawardhani, A., \& McCarthy, G. (2013). Innovation in Small and Medium-Sized Wood-Furniture Firms in Central Java, Indonesia. Proceedings of the International Conference on Managing the Asian Century, 471-480. https://doi.org/10.1007/978-981-4560-61-0_53

LAGO. (2021a). Discover LAGO Design Furniture to decorate your Home / LAGO Design. https://www.lago.it/en/

LAGO. (2021b). LAGO opens its first single-brand store in China, in Shanghai's City Centre. https://www.lago.it/en/lago-opens-its-first-single-brand-store-in-china-in-shanghais-city-centre/

LAGO. (2021c). Loto Table. https://configurator.lago.it/en/configurator/TAV1900?options\%5BDPN\%5D=LOT1\&options\%5BG MB\%5D=NER\&options\%5BPTV\%5D=ROS\&options\%5BPRL\%5D=SZ2 
Lameman, B. A., El-Nasr, M. S., Drachen, A., Foster, W., Moura, D., \& Aghabeigi, B. (2010). User studies. 134. https://doi.org/10.1145/1920778.1920798

Luisaviaroma. (2021). About us. https://www.luisaviaroma.com/en-ch/contactus/about-us

Marilungo, E., Papetti, A., Germani, M., \& Peruzzini, M. (2017). From PSS to CPS Design: A Real Industrial Use Case Toward Industry 4.0. Procedia CIRP, 64, 357-362.

https://doi.org/10.1016/j.procir.2017.03.007

Masood, T., \& Sonntag, P. (2020). Industry 4.0: Adoption challenges and benefits for SMEs. Computers in Industry, 121, 103261. https://doi.org/10.1016/j.compind.2020.103261

Morelli, N. (2006). Developing new product service systems (PSS): methodologies and operational tools. Journal of Cleaner Production, 14(17), 1495-1501.

https://doi.org/10.1016/j.jclepro.2006.01.023

Mueller, R. M., \& Thoring, K. (2012). Design Thinking Vs Lean Startup: A Comparison of Two Userdriven Innovation Strategies. In Proceedings of 2012 International Design Management Research Conference (Issue January 2016). https://doi.org/10.13140/2.1.1834.4647

Odoom, R., Narteh, B., \& Boateng, R. (2017). Branding in small- and medium-sized enterprises (SMEs): Current issues and research avenues. Qualitative Market Research, 20(1), 68-89. https://doi.org/10.1108/QMR-12-2015-0091

OECD Skills Outlook. (2017). OECD iLibrary / Home. https://www.oecdilibrary.org/sites/9789264273351-4-en/index.html?itemld=/content/component/97892642733514-en

Otero-Neira, C., Lindman, M. T., \& Fernández, M. J. (2009). Innovation and performance in SME furniture industries: An international comparative case study. Marketing Intelligence and Planning, 27(2), 216-232. https://doi.org/10.1108/02634500910944995

Ozcan, S. (2008). KOBI'Lerde Markalasma SorununuTespiti Ve TutundurFaaliyetlerinGelistirilmesiUzerine KonyaTekstil-HaziGiyimSanayiBolgesindeBir Uygulama.

Pagliacolo, E. (2015). A Major Lighting Innovation at Viabizzuno. https://www.azuremagazine.com/article/milan-design-week-day-2-a-major-lighting-innovation-atviabizzuno/

Paksoy, M., Kara, M., Prof, Y., Co, H., Yrd, E., Yrd, B., Yrd, M. K., Divano, S. U., Yrd, K., \& Ak, Y. (n.d.). Tuketici davranislari.

Rauch, E., Vickery, A. R., Brown, C. A., \& Matt, D. T. (2020). SME requirements and guidelines for the design of smart and highly adaptable manufacturing systems. In Industry 4.0 for SMEs: Challenges, Opportunities and Requirements. https://doi.org/10.1007/978-3-030-25425-4_2

Taft, R. (2019). The Convergence of Storytelling and Personalized Marketing Automation. https://www.martechadvisor.com/articles/content-marketing/the-convergence-of-storytellingand-personalized-marketing-automation/

The World Upholstered. (2019). 2019-2020.

Tukker, A. (2004). Eight types of product-service system: Eight ways to sustainability? Experiences from suspronet. Business Strategy and the Environment, 13(4), 246-260. https://doi.org/10.1002/bse.414

United Nations Conference on Trade and Development. (2010). Integrating Developing Countries ' SMEs into Global Value Chains. United Nations Conference on Trade and Developement, 120.

Urata, S. (2021). Urata Enhancing SME Participation in Global Value Chain. ADBInstitute

Zuperkiene, E., Simanskiene, L., Labanauskaite, D., Melnikova, J., \& Davidaviciene, V. (2021). The COVID-19 Pandemic and Resilience of SME's in Lithuania. Entrepreneurship and Sustainability Issues, 8(3), 53-65. https://doi.org/10.9770/jesi.2021.8.3(4) 
Author Bios:

Özge Şahin, Master student at Jiangnan University/School of Design Wuxi. She obtained a bachelor's in Economics from Istanbul University in 2016. Her research direction is Brand and Design Strategy of Furniture SMEs.

Prof. Gabriele Goretti, Associate Professor at Jiangnan University/School of Design, Wuxi, co-director of Future Brand Experience Design Lab. His professional profile focuses on relations in between design strategies, high-end manufacturing and communication processes in interiors and fashion areas.

Prof. Qian Xiaobo, Associate Professor at Jiangnan University/School of Design, Wuxi, director of Future Brand Experience Design Lab. PhD from Politecnico di Milano. Her professional research and practice focuse on design strategies, PSSD, and customization.

Acknowledgements: Thanks to the LAGO Design for their contribution, which is used as the main example brand in this article and provided significant images of their Products Service System. 